Misr J. Ag. Eng., 26(1): 11-43

FARM MACHINERY AND POWER

\title{
SELECTING THE BEST REMOTE SENSING PLATFORM FOR AGRICULTURAL ASSESSMENT USING MULTI-OBJECTIVE ANALYSIS
}

\author{
A. Roanhorse ${ }^{1}$, D. El Shikha ${ }^{2}$, F. Szidarovszky ${ }^{3}$, P. Waller ${ }^{1}$ \\ ABSTRACT
}

Remote sensing has been identified as a cost-effective technology for sitespecific management. This technology offers geographically extensive and continuous assessment of plants, soil and water resources, and other land surface phenomena. Selection of the best available remote sensing technology is determined in most cases by platform and sensor attributes. If these attributes can be quantified, then a multi-objective analysis may be performed to assess quantitatively the tradeoffs between different sensor and platform attributes, identifying the best overall technology. Pioneer work was presented by applying multi-objective analyses to remote sensing technology. Experts were surveyed to identify the best overall technology for agricultural purposes at three different pixel sizes: very fine $(<5 \mathrm{~cm})$, fine to moderate $(0.5 \mathrm{~m}-1.0 \mathrm{~m})$, and moderate to coarse resolutions $(0.1 \mathrm{~km}-1.0 \mathrm{~km})$. Platform technologies included hand held sensors, booms, remotely piloted vehicles, unmanned aerial vehicles, manned aircraft, Quickbird, Landsat, AVHRR, MODIS, ASTER, and SPOT. Plurality voting, Borda count, Hare system, and pairwise voting were used to analyze survey responses. Results suggest hand held sensors and manned aircraft platforms were favored for applications requiring very fine and fine to moderate spatial resolutions. AVHRR and MODIS were rated equally as the best alternatives for applications requiring moderate to coarse resolution imagery.

Keywords: multi-objective analysis; remote sensing; social choice; decision-making

1- Dept. of Agric. and Biosystems Engineering, University of Arizona, Tucson, AZ, USA

2- Agric. Eng. Dept., Mansoura University, Al Mansoura, Egypt

3- Systems and Industrial Engineering Dept., University of Arizona, Tucson, AZ, USA 


\section{INTRODUCTION}

$\mathrm{R}$ emote sensing imagery allows for quick and continuous assessments on local, regional and global scales, and thus, is an effective method of monitoring and assessing vegetation (i.e., discriminating vegetation type, vigor, chlorophyll concentration, and biomass), soils and geology (i.e., clay minerals, iron minerals, carbonates, and sulfates), snow and ice hydrology, desertification and drought, oceanography and limnology, and atmosphere (i.e., ice clouds, water clouds, ozone, methane water vapor, aerosols, smoke, oxygen, and carbon dioxide) (Jensen 1996). Other advantages of remote sensing technologies include the availability of synoptic scenes, varied spatial resolutions, multi-spectral data, multi-temporal coverage, cost effectiveness, and the ability to monitor inaccessible areas (Joshi et al. 2004). Remote sensing observations have been used to evaluate the biotic effects of grazing (Lusby 1970); estimating gross primary production (Hunt et al. 2005); conduct landscape-level evaluations of plant community distribution and patch dynamics (Booth et al. 2003); mapping the actual and predicting the potential distribution of invasive species (Joshi et al. 2004); plant and animal inventories; and hydrology (i.e., runoff, erosion, and infiltration).

Jackson (1984) and Moran et al. (1997) reported limitations of satellite data include restricted spectral range, coarse spatial resolution, slow turn around time, and the inadequate repeat coverage. Satellite-based sensors have fixed spectral bands that are not applicable to project objectives and the spatial resolution too coarse to detect in-field variability. Satellite imagery vary in spectral, spatial, and temporal resolutions and is available from numerous providers. Regardless of the satellite platform/model, the spectral and spatial resolutions are set (i.e., no modifications can be made with respect to changing band or band widths). In comparison to other available satellites, AVHRR and MODIS are available at no cost, pass every 1-2 days, and have set spectral bands with coarse spatial resolutions ranging from $0.25 \mathrm{~km}$ to $1 \mathrm{~km}$. These data sets are useful for monitoring at global, continental, and biome scales as they generate continuous seasonal and year-to-year data. In contrast, high resolution imagery from the Quickbird satellite developed and operated by Digital-Globe provides $61-\mathrm{cm}$ panchromatic and 2.44-m multi-spectral images at nadir. A $60 \mathrm{~cm}$ 
pixel resolution, orthorectified, 4 band, pan-sharpened, $<500 \mathrm{~km}^{2}$ from Eurimage costs $\$ 2,700$ (Eurimage 2007). Finally, satellite imagery requires extensive training in image acquisition, analysis, and interpretation.

Moran (1994) reported numerous disadvantages associated with SPOT, HRV, and Landsat TM satellite data for day-to-day irrigation management decisions. The study made an effort to acquire every possible SPOT and Landsat image for an entire growing season. Only $31 \%$ of the forecasted satellite data acquisition opportunities were realized. A majority of failures were due to weather conditions (i.e., cloud, cirrus, cumulus, and haze) or technical difficulties (i.e., conflicts at the receiving station, the sensor view angle was of opposite sign with a view angle of $+12^{\circ}$, programming errors, failure to order satellite data, sensor calibration, and atmospheric interference). Advantages of satellite imagery are repeat coverage over the same location at the same altitude, time, and orbital inclination. Another advantage is the availability of highly processed images that have been orthorectified to correct distortions resulting from the earth's curvature and rotation, satellite motion, viewing perspective, and relief displacement (Aronoff 1993).

Airplanes and helicopters have the ability to collect data more frequently, which is particularly important during periods when close monitoring of pending stress (i.e., infestations and drought) is critical (Thomson et al. 2005) or when disaster strikes (i.e., fires and floods). Although the type of aircraft used depends on the requirement of the data collected, fixedwinged aircraft is the usual platform of choice (Falkner and Morgan 2002). Many projects that require large-scale imagery over relatively small areas can be accomplished in a day with a single-engine aircraft (Falkner and Morgan 2002). Historically, the expense of data collection from manned aircraft and/or satellites has led to limited implementation, especially for real time management in natural resources and agriculture. Although the cost of satellite imagery is declining, the cost of aircraft is still prohibitive for many research projects, particularly those requiring repetitive monitoring.

A disadvantage of using airplanes is the instability of the platform that affects the exterior orientation (i.e., position and angular orientation) of the image $\left(X_{o}, Y_{o}\right.$, and $\left.Z_{o}\right)$, making image rectification difficult (Laliberte et al., 2008; Leica Geosystems 2005). The camera's angular rotation is 
expressed as omega $(\omega)$, phi $(\varphi)$, and kappa $(\kappa)$. This describes the relationship between the ground space coordinate system $(X, Y$, and $Z)$ and the image space coordinate system ( $x, y$, and $z$ ) (Leica Geosystems 2005). Rotation about the camera axis results in distortions in the image and image coordinates (Laliberte et al., 2008; Lee 1941). These distortions increase from the center and out towards the image perimeter (Laliberte et al., 2008; Leica Geosystems 2005). In addition, the orthorectification and mosaicing of multiple aircraft images requires an overlap of $60 \%$ along the flight line and a $20 \%-30 \%$ sidelap along parallel strips or flight lines (Laliberte et al., 2008; Leica Geosystems 2005). The required distance between flight lines is dependent on the camera view angle and the altitude above ground level (Jensen 1996). Flying at lower altitudes produces higher resolution images but this requires more flight lines and processing in comparison to operations flown at higher altitudes and this can be a disadvantage (Jensen 1996).

RPVs and UAVs are increasing popular alternatives to satellite and manned aircraft. Other terms that have been used to describe remotely controlled platforms include, Unmanned Vehicle Systems (UVS), Automatically Piloted Vehicles (APV), Remotely Operated Aircrafts (ROA), pilotless airplanes, Remote Controlled airplanes (RC-airplanes), model airplanes, and drones (Eisenbeiss 2004). The name UAV covers all vehicles capable of programmable flight patterns and operated without human intervention (Eisenbeiss 2004).

RPVs and UAVs provide an effective, low cost alternative to traditional platforms for acquiring high-resolution images $(5 \mathrm{~cm}-30 \mathrm{~cm}$ pixel size) at relatively low costs (Rango et al. 2006, Laliberte et al., 2008). Unlike satellite and high altitude photography $(4,000 \mathrm{~m}-6,000 \mathrm{~m}$ above ground level), high spatial resolution imagery from RPVs and UAVs provide differentiation of vegetation and landscape features necessary to classify, map, and monitor ecosystem changes at the local and regional levels. These systems share the same orientation challenge as airplanes, to a greater extent, because they are considerably smaller in size and are more susceptible to wind effects (Laliberte et al., 2008).

Low-cost, high-resolution digital photography from RPVs and UAVs have been used in identifying root-rot fungus (Phellinus weirii) infection in Douglas fir (Pseduotsuga menziessi) (Tomlins and Lee 1983), to evaluate vineyard health (Johnson et al. 2002), coffee bean ripeness 
(Herwitz et al. 2002; Johnson et al. 2002), nutrient status of corn and crop biomass of corn, alfalfa, and soybeans (Hunt et al. 2005), yield estimation in citrus (MacArthur et al. 2005), and for weed mapping (Hardin and Jackson 2005).

Hand-held sensors are the easiest type of sensor to deploy. These sensors can be held with the hand (Stark and Gitelson 2000) or fixed to a handheld mast (Price et al. 1993). Disadvantages of hand-held sensors include time consuming data collection; site accessibility limitations (i.e., dense vegetation, lack of roads, and flooded areas) (Rango et al. 2006); and disturbances to the study area (Shumand and Ambrose 2003).

Over the past four decades, scientists have developed various motorized ground-based sensor systems and booms (Rundquist et al. 2004). These technologies provide very high spatial and taxonomic resolutions on small spatial scales and are commonly used to ground truth aerial data (Phinn et al. 1996; Rango et al. 2006). Booms were developed and utilized in several recent studies (Barnes et al. 2000; Peterson et al. 2002; Colaizzi et al. 2003a; Colaizzi et al. 2003b; Kostrzewski et al. 2003; Scotford and Miller 2004; Xue et al. 2004; El-Shikha et al. 2007) that measured reflectance at specific bands with the sensors carried through the field by tractors and center pivot or linear move irrigation systems. Spectral data collection with motorized booms is more systematic than hand-held sensors because they maintain constant elevation and sensor orientation. (Rundquist et al. 2004).

Selection of the remote sensing technologies is determined, in most cases, by platform and sensor attributes (i.e., cost, efficiency, flexibility, payload capacity, spatial coverage, and spatial, spectral, and temporal resolutions). If these attributes can be quantified, then a multi-objective analysis may be performed to assess quantitatively the tradeoffs between different sensor and platform attributes, identifying the best overall technology. We present pioneering work by applying multi-objective analyses to remote sensing technology selection. Experts were surveyed to identify the best overall technology at three different pixel sizes: very fine $(<5 \mathrm{~cm})$, fine to moderate $(0.5 \mathrm{~m}-1.0 \mathrm{~m})$, and moderate to coarse resolutions $(0.1 \mathrm{~km}-$ $1.0 \mathrm{~km}$ ). Platform/sensor technologies (Table 1) included hand held sensors and booms in Group 1; RPVs, UAVs, and manned aircraft in Group 2; and Quickbird, Landsat, AVHRR, MODIS, ASTER, and SPOT in Group 3. The platform attributes considered in identifying the best 
overall technology were system and data costs, efficiency, flexibility, payload capacity, spatial coverage, and spatial, spectral, and temporal resolutions (Table 2). The multi-objective analysis methods used included plurality voting, Borda count, Hare system, and pairwise voting.

Table 1. List of remote sensing technologies.

\begin{tabular}{cll}
\hline Group 1 & \multicolumn{1}{c}{ Group 2 } & \multicolumn{1}{c}{ Group 3 } \\
\hline$A_{1}=$ automated booms & $A_{3}=$ RPVs & $A_{6}=$ Quickbird \\
$A_{2}=$ hand held sensors & $A_{4}=$ UAVs & $A_{7}=$ Landsat \\
& $A_{5}=$ manned aircraft & $A_{8}=$ AVHRR \\
& & $A_{9}=$ MODIS \\
& & $A_{10}=$ ASTER \\
& $A_{11}=$ SPOT
\end{tabular}

\section{SOCIAL CHOICE METHODOLOGY}

This paper implements a multi-objective analysis to quantitatively assess and rank eleven remote-sensing technologies on the basis of nine different attributes. First, participants were instructed to weigh the importance of each attribute relative to the others. Second, each participant assigned a numerical rating as to how well each attribute is captured or fulfilled by each platform. And third, the "overall best" technology is selected.

\section{Weighing each attribute}

The eleven different remote sensing platform alternatives are listed in Table 1, where they are organized into three groups. The survey considered nine attributes, which are given in Table 2. The experts weighed the importance of the attributes with the constraint that the sum of weights equals 100. For example, Expert A may consider all nine attributes equally important, and would thus assign them all equal importance factors of 11.11 (sum to 100). At the other extreme, Expert B, may consider system cost the most constraining attribute and assign it 100, with all other attribute weights equal to zero (again sum to 100). In all likelihood, the importance factors will fall somewhere between these two cases, with attributes having differing weights in accordance with the expert preferences. 
Table 2. Platform attributes and rating scale.

\begin{tabular}{|c|c|c|}
\hline \multirow[b]{2}{*}{ Attribute Definition } & \multicolumn{2}{|c|}{ Rating } \\
\hline & 1 & 10 \\
\hline System cost - expense to build, launch, and/or maintain & Low & High \\
\hline $\begin{array}{l}\text { Data cost -collection, image registration, georectification, } \\
\text { and/or dissemination }\end{array}$ & Low & High \\
\hline Efficiency & High & Low \\
\hline $\begin{array}{l}\text { Flexibility - ease of deployment, change in sensor } \\
\text { configuration, time of day, and/or flying altitude }\end{array}$ & & Low \\
\hline Payload capacity - space and weight limitations & High & Low \\
\hline Spatia & Large & Small \\
\hline Spatial resolution & High & Low \\
\hline Temporal resolution & High & Low \\
\hline Spectral resolution & High & Low \\
\hline Rating different technologies & & \\
\hline \multicolumn{3}{|c|}{$\begin{array}{l}\text { The platform/sensor technology must be comparatively assessed within } \\
\text { the context of the nine attributes. Each expert, using his or her } \\
\text { professional judgment assigns a numerical rating from } 1 \text { to } 10 \text { for each } \\
\text { technology attribute, with } 1 \text { designating that the technology "excels" in } \\
\text { performance with respect to the other technologies for a particular } \\
\text { attribute, and } 10 \text { designating the technology performs "poorly" with } \\
\text { respect to the other technologies for a particular attribute. For example, } \\
\text { an expert may rate AVHRR and MODIS system and data costs as } 1 \\
\text { because data are available at no cost. Finally, there is no technology that } \\
\text { fulfills all attributes to the highest possible level, consequently, no } \\
\text { technology will provide both high resolution (e.g., } 5 \mathrm{~cm} \text { ) and a large } \\
\text { footprint (e.g., } 1.1 \mathrm{~km} \text { ). The assigned values are used in the multi- } \\
\text { objective analysis to determine the "best overall technology." Plurality } \\
\text { voting, Borda count, Hare system, and pairwise voting were used to } \\
\text { analyze survey responses. }\end{array}$} \\
\hline
\end{tabular}




\section{Selecting overall best technology}

All of the methods use a decision matrix. It is assumed that several decision makers have to select a commonly acceptable alternative from a finite set of choices. Let $m$ be the number of decision makers and $n$ the number of alternatives to select from. Each decision maker gives a ranking of the alternatives with the numbers 1 through $n$, where 1 is given to the most preferred alternative, 2 is given to the second most preferred one, etc., $n$ is given to the least preferred alternative. If the data given by all decision makers are ordered in a matrix in which the rows correspond to the decision makers and the columns to the alternatives, then a $m \times n$ matrix is obtained, each row of which is a permutation of the numbers 1 , $2, \ldots, n$. The $(i, j)$ element of this matrix is denoted by $a_{i j}$ which shows the ranking of alternative $j$ by decision maker $i$. Based on this matrix several social choice methods can be used to identify the best commonly acceptable alternative.

Plurality Voting. For each alternative we first compute the number of decision makers that have this alternative as their best choice and then determine the alternative that has the largest number of such votes. Mathematically, for each alternative we determine the value of:

$$
A_{j}=\sum_{i=1}^{m} f\left(a_{i j}\right)
$$

where for all $i$ and $j$,

$$
f\left(a_{i j}\right)= \begin{cases}1 & \text { if } a_{i j}=1 \\ 0 & \text { otherwise. }\end{cases}
$$

The social choice is alternative $j^{*}$, if

$$
A_{j^{*}}=\max \left\{A_{1}, A_{2}, \ldots, A_{n}\right\}
$$


Borda Count. The major drawback of plurality voting is the fact that it considers only the most preferred alternatives of the decision makers and does not take less important rankings into account. The Borda count considers all less important rankings by computing the sum of the rankings by all decision makers for each alternative:

$$
B_{j}=\sum_{i=1}^{m} a_{i j}
$$

and alternative $j^{*}$ is consider to be the social choice if

$$
B_{j^{*}}=\min \left\{B_{1}, B_{2}, \ldots, B_{n}\right\}
$$

Notice that smaller ranking means higher priority by the decision makers, therefore the smallest $B_{j}$ value shows the highest overall ranking.

The Hare System. This is a sequential method, which iteratively eliminates less overall preferred alternatives. In the first step, we calculate the values $A_{1}, A_{2}, \ldots, A_{n}$ as in applying plurality voting. These numbers show how many decision makers select each alternative as their best choices. If there is an alternative that is considered the most preferred by at least half of the decision makers (that is when $A_{j} \geq m / 2$ ) this alternative is the social choice, and the procedure terminates. Otherwise the alternative with the smallest $A_{j}$ value is eliminated, and the procedure starts from the very beginning with the original $m$ decision makers and the remaining $n-1$ alternatives. If alternative $j_{o}$ is eliminated, then the elements $\left(j \neq j_{o}\right)$ of the new decision matrix can be updated as:

$$
a_{i j}^{\text {new }}=\left\{\begin{array}{cc}
a_{i j} & \text { if } \quad a_{i j}<a_{i j_{o}} \\
a_{i j}-1 & \text { otherwise. }
\end{array}\right.
$$

In order to keep the original identification (indices) of the alternatives, they have to be kept on the top of the decision matrix. After repeating the above elimination step sufficiently many times, at least one alternative 
will have at least $m / 2$ best preferred rankings and then the procedure terminates.

Pairwise voting. There are several variants of this method; each of them is based on the comparisons of two given alternatives. This is done in the following way. Let $j$ and $j$ ' be two alternatives. Let $N(j, j$ ') show how many decision makers give a more preferred ranking to alternative $j$ than to alternative $j$ '. Mathematically,

$$
\begin{aligned}
& N\left(j, j^{\prime}\right)=\sum_{i} 1 . \\
& \mathrm{a}_{\mathrm{ij}}<\mathrm{a}_{\mathrm{ij}},
\end{aligned}
$$

Alternative $j$ is considered overall more preferred than alternative $j$, , if $N\left(j, j^{\prime}\right)>m / 2$. Notice that this is the case if more than half of the decision makers give higher preference to alternative $j$ than to alternative $j$ '.

One variant of pairwise voting is to determine all alternatives $j$ for which there is no other alternative $j$ ' that is overall more preferred than alternative $j$. These alternatives are called non-dominated or Pareto optimal, and all of them are presented to the decision makers. In the case of multiple solutions another method has to be used based on the nondominated alternatives to select only one social choice.

Another variant of this method is based on an agenda of pairwise comparisons that is agreeable by all decision makers. This agenda gives an order, $j_{1}, j_{2}, \ldots, j_{\mathrm{n}}$ of the $n$ alternatives. First alternatives $j_{1}$ and $j_{2}$ are compared by pairwise voting. The overall more preferred is considered the winner, which is then compared to $j_{3}$. The winner is compared again to $j_{4}$ etc. In the last step the winner of the $(n-2)$ nd comparison is compared to $j_{\mathrm{n}}$, and the winner of this final comparison is considered and accepted as the social choice. If in any earlier step the two compared alternatives are equally preferred overall, then the process continues with both of them. 


\section{$\underline{\text { RESULTS }}$}

The attribute rankings for each decision maker are presented in Table 3 (Appendix) and their technology attribute ratings are provided in Table 4 (Appendix). In Table 3, the rows correspond to the experts providing the rankings and the columns correspond to the attributes. Table 4 has five parts each of them presents the evaluation of the different alternatives with respect to the attributes by each of the experts. In order to quantitatively assess the various technologies, each attribute was multiplied by the corresponding weight the experts provided in part 1 of the survey (Table 5, Appendix). Next, the sum of each technology attribute was determined (Table 6, Appendix) which represents the weighted sums of the evaluation numbers. And finally, the rankings of the alternatives were determined based on these weighted sums. The rankings are shown in Table 7 (Appendix). The alternatives were divided into three groups, Group 1 consisting of alternatives 1 and 2; Group 2 consisting of alternatives 3, 4, and 5; and Group 3 consisting of the last 6 alternatives. The rankings were done independently for the three groups. The above methods were applied based on the expert ratings. The details are given as follows:

In applying plurality voting, the most preferred alternative is the one which received the highest rankings. The number after each alternative represents the number of top rankings.

According to table 7:

Group $1 \quad A_{1}=0, A_{2}=3$

Group $2 \quad A_{3}=1, A_{4}=1, A_{5}=3$

Group $3 A_{6}=1, A_{7}=0, A_{8}=2, A_{9}=1, A_{10}=1$, and $A_{11}=0$. 
Since hand held sensors, manned aircraft, and AVHRR have received the highest count of 1's, they are considered the social choices for Groups 1, 2 , and 3 , respectively.

Borda count computes the sum of all rankings (i.e., sum of each row in Table 7). The results are given below:

\section{Group 1}

$A_{l}=2+2+0.5+2+0.5=7$

$A_{2}=1+1+0.5+1+0.5=4$

\section{Group 2}

$A_{3}=1+3+3+2+3=12$

$A_{4}=2+2+1+3+2=10$

$A_{5}=3+1+2+1+1=8$

\section{Group 3}

$A_{6}=3+1+5+6+6=21$

$A_{7}=2+5+6+4+4.5=21.5$

$A_{8}=6+3+2+1+1=13$

$A_{9}=4+2+1+2+2=11$

$A_{10}=1+3+4+3+3=14$

$A_{11}=5+6+3+5+4.5=23.5$.

Again, hand held sensors $\left(A_{2}=4\right)$, manned aircraft $\left(A_{5}=8\right)$ and MODIS $\left(A_{9}=11\right)$ had the lowest sums of rankings and they were therefore accepted as the best alternatives.

In applying the Hare system for Groups 1 and 2, the best choices are hand held sensors $\left(A_{2}\right)$ and manned aircraft $\left(A_{5}\right)$ since they received best 
rankings from at least half of the experts. However, for the third group none of the alternatives received at least three votes and elimination must be used. Landsat and SPOT received no best rankings, so they are eliminated and the remaining alternatives ranked. The modified table is given in Table 8 (Appendix). Since none of the alternatives got at least 3 best rankings, the alternatives with the least number of best rankings are eliminated. They are Quickbird, MODIS, and ASTER. The only remaining alternative, AVHRR $\left(A_{8}\right)$, is the social choice.

Table 7 was used in the pair-wise computations summarized in Table 9 (Appendix) and illustrated in Figure 1. In Group 1, 3 decision makers preferred hand held sensors $\left(A_{2}\right)$ and one preferred booms, so hand held sensors is the better choice. In Group 2, the overall best alternative is manned aircraft $\left(A_{5}\right)$. In Group 3, MODIS $\left(A_{9}\right)$ was the most preferred choice, since it was better than all other alternatives, so it is the social choice.

\section{DISCUSSION}

Jensen (1996) categorized remote sensing spatial scales into global (AVHRR $1.1 \mathrm{~km}$ ), continental (AVHRR, Landsat MSS $1.1 \mathrm{~km}-80 \mathrm{~m}$ ), biome (Landsat MMs, TM, Synthetic aperture radars $80 \mathrm{~m}-30 \mathrm{~m}$ ), regional (TM, high altitude aircraft, large format camera, SPOT $30 \mathrm{~m}-3 \mathrm{~m}+$ ), plot (high and low altitude aircraft $3 \mathrm{~m}-1 \mathrm{~m}$ ), and in-situ sample site (i.e., surface measurements and observations). Funding and logistical limitations require project managers to implement the most available and efficient methods of data collection (Shumand and Ambrose 2003).

In general, ground based methods provide data of the highest resolution and are better suited for small scale projects (Shumand and Ambrose 2003). Ground based data collection at regional scales is cost prohibitive (Shumand and Ambrose 2003). Handheld sensors and booms are limited by site accessibility, but booms are constrained in three-dimensions (i.e., trees and buildings). The spatial coverage of booms is affected by their tendency to sway. One expert considered this an inconvenience while another expert used it to his advantage. Hand held sensors were 
consistently identified as the sensor and platform of choice for Group 1 (i.e. very high resolution).

All experts participating in the survey had limited experience using RPVs and UAVs. In evaluating manned aircraft, one of the experts included the AVRIS system. AVRIS is flown on four different aircraft platforms at 4 to $20 \mathrm{~km}$ above sea level (NASA Jet Propulsion Laboratory 2007) and collects hyperspectral data at 5 to $20 \mathrm{~m}$ pixel resolution. This high performance system was not considered in the survey design. Manned aircraft were consistently identified as the best technology in Group 2 for all social choice methods.

For Group 3 (i.e., moderate to coarse pixel resolution), plurality voting and the Hare system identified AVHRR as the best alternative but the identification of a single technology was not feasible using Borda count and pairwise voting. AVHRR, MODIS, and ASTER were tied using these methods.

\section{CONCLUSION}

This multi-objective analysis addresses the conflicting objectives in remote sensing platform selection as related to natural resource management. The determination of the "best overall technology" was based in accordance with expert preferences. First, participants were instructed to weigh the importance of each attribute relative to the others. Second, each participant assigned a numerical rating as to how well each attribute is captured or fulfilled by each platform. The attributes presented included, cost, efficiency, flexibility, payload capacity, spatial coverage, and spatial, spectral, and temporal resolutions. The considerations of all of these attributes are not applicable to all of the platforms presented. For example, researchers did not acquire the cost of satellite systems nor was there control over payload capacities. Third, a special multi-criteria method, social choice was applied for the final selection.

The computed results consistently identified hand held sensors and manned aircraft to be the best overall technology for very fine $(<5 \mathrm{~cm})$ and fine to moderate $(0.5 \mathrm{~m}-1.0 \mathrm{~m})$ pixel resolutions, respectively. 
AVHRR and MODIS were tied as best alternatives for moderate to coarse $(0.1 \mathrm{~km}-1.0 \mathrm{~km})$ pixel resolution imagery. Although there were limitations of the methods, they can be expanded in the future to include more experts and attributes to provide a more robust analysis.

\section{REFERENCES}

Aronoff, S. 1993. Geographic Information Systems: A Management Perspective. 3rd ed., 294 pp (WDL Publications; Ottowa, Canada).

Barnes, E. M., T. R. Clarke, P. Colaizzi, J. Haberland, M. Kostrzewski, E. Riley, S. M. Moran, P. M. Waller, C. Choi, T. Thompson, S. Richards, R. Lascano and H. Li. 2000. Coincident detection of crop water stress, nitrogen status, and canopy density using ground-based multispectral data. In Proceedings of the 5th International Conference on Precision Agriculture, 16-29 July 2000, Bloomington, MN.

Booth, D. T., D. Glenn, B. Keating, J. Nance, S. E. Cox and J. P. Barriere. 2003. Monitoring rangeland watersheds with very-large scale aerial imagery. Proceedings of the First Interagency Conference on Research in the Watersheds), October 27-30, 2003, Benson, Arizona, pp 212-215.

Colaizzi, P. D., E. M. Barnes, T. R. Clarke, C. Y. Choi and P. M. Waller. 2003a. Water stress detection under high frequency sprinkler irrigation with water deficit index. ASCE Journal of Irrigation and Drainage Engineering, 129(1), 36-43.

Colaizzi, P. D., E. M. Barnes, T. R. Clarke and P. M. Waller. 2003b. Estimating soil moisture under low frequency surface irrigation using crop water stress index. ASCE Journal of Irrigation and Drainage Engineering, 129, 27-35.

EISENBEISS, H. 2004. A mini Unmanned Aerial Vehicle (UAV): System overview and image acquisition. In International Workshop on "Processing and Visualization Using High-Resolution Imagery", November 18-20, 2004, Pitsanulok, Thailand. 
El-Shikha, D. M., P. M. Waller, D. Hunsaker, T. R. Clarke and E. M. Barnes. 2007, Ground-based remote sensing for assessing water and nitrogen status of broccoli. Agricultural Water Management, 92, pp. 183-193.

EuRIMAGE (2007) Eurimage Price List 2007. Available online at: http://www.eurimage.com/products/docs/eurimage_price_list.pdf (accessed 10 July 2007).

FAlKner, E. and D. Morgan. 2002. Aerial Mapping: Methods and Applications. (Boca Raton, FL: CRC Press).

Hardin, P. J., and M. W. Jackson. 2005, An unmanned aerial vehicle for rangeland photography. Rangeland Ecology and Management, 58, 439-442.

Herwitz, S. R., L. F. Johnson, J. Arvesen, R. Higgins, J. Leung and S. Dunagan. 2002. Precision agriculture as a commercial application for solar-powered unmanned aerial vehicles. In First American Institute of Aeronautics and Astronautics UAV Conference, Portsmouth, Virginia, (Portsmouth, Virginia: American Institute of Aeronautics and Astronautics, Inc).

Hunt Jr., E. Raymond, M. Cavigelli, C. S. Daughtry, J. E. McMurtrey and C. L. Walthall. 2005. Evaluation of digital photography from model aircraft for remote sensing of crop biomass and nitrogen status. Precision Agriculture, 6, 359-378.

JACKSON, R. D. 1984. Remote sensing of vegetation characteristics for farm management. Proceedings of the Society of Photo-Optical Instrumentation Engineers, 475, 81-96.

Jensen, J. R. 1996. Introductory digital image processing: A remote sensing perspective, Saddle River: Prentice-Hall, 318, 379 P.

Johnson, L. F., S. R. Herwitz, B. M. Lobitz and S. Dunagan. 2002. Feasibility of monitoring coffee field ripeness with airborne multispectral imagery. Applied Engineering in Agriculture, 20, 845849. 
Joshi, C., J. de Leeuw and I. C. van Duren. 2004. Remote sensing and GIS applications for mapping and spatial modeling of invasive species. Proceedings of the XXth ISPRS Congress, July 12-23, 2004, Instanbul, Turkey pp. 669-677.

Kostrzewski, M., P. M. Waller, P. Guertin, J. Haberland, P. D. Colaizzi, E. M. Barnes, T. Thompson, T. R. Clarke, E. Riley and C. Y. Choi. 2003. Ground-Based remote sensing of water and nitrogen stress. 46, 29-38.

Laliberte, A. S., A. Rango, V. Jenkins and A. Roanhorse. 2008. Acquisition, orthorectification and classification of sub-decimeter resolution imagery obtained with an unmanned aerial vehicle (UAV). ISPRS Journal of Photogrammetry and Remote Sensing (In press).

Lee, H.C. 1941. Aerial photography, a method for fuel type mapping. Journal of Forestry, 39, 531-533.

Leica Geosystems. 2005. ERDAS Field Guide. Leica Geosystems Geospatial Imaging, LLC,

Lo, C. P. 1986. Applied remote sensing. pp. 393 (New York: John Wiley and Sons Inc.)

Lusby, G.C. 1970. Hydrologic and biotic effects of grazing vs. nongrazing near Grand Junction, Colorado. 700-B, pp. 232-236.

MacArthur, D. K., J. K. Schueller and C. D. Crane. 2005. Remotelypiloted mini-helicopter imaging of citrus. In ASAE Annual International Meeting (Paper No. 051055), Tampa, FL: ASAE.

MORAN, S. M. 1994. Irrigation management in Arizona using satellites and airplanes. Irrigation Science, 15, 35-44.

Moran, S. M., Y. Inoue and E. M. Barnes. 1997. Opportunities and limitations for image-based remote sensing in precision crop management. Remote Sensing of Environment, 61, 319-346. 
NASA Jet Propulsion Laboratory. 2007. AVIRIS (Airborne Visible/Infrared Imaging Spectrometer) Available online at: http://aviris.jpl.nasa.gov/ (accessed 15 July 2007).

Peterson, C. T., C. R. Jensen and V. O. Mogensen. 2002. Analysis of variation of spectral vegetation index measured in differently fertilized field barley. Communications in soil science and plant analysis, 33, 1485-1506.

Phinn, S. R., D. A. Stow and J. B. Zedler. 1996, Monitoring wetland habitat restoration in southern California using airborne multispectral video data. Restoration Ecology, 4, 412-422.

Price, K., M. V. E. Varner, D. Rundquist and J. Peake. 1993. Influences of land management and weather on plant biophysical and hyperspectral response patterns of tallgrass prairies in Northeastern Kansas. Proceedings, PECORA-12 Symposium, August 24-26, 1993, Sioux Falls, South Dakota, pp. 441-450.

Rango, A., A. Laliberte, C. Steele, J. E. Herrick, B. Bestelmeyer, T. Schmugge, A. Roanhorse and J. Jenkins. 2006. Using unmanned aerial vehicles for rangelands: current applications and future potentials. Environmental Practice, 8, 159-168.

Rundquist, D., R. Perk, B. Leavitt, G. Keydan and A. Gitelson. 2004. Collecting spectral data over cropland vegetation using machinepositioning versus hand-positioning of the sensor. Computers and Electronics in Agriculture, 43, 173-178.

Scotford, I. M. and P. C. H. Miller. 2004. Combination of spectral reflectance and ultrasonic sensing to monitor the growth of winter wheat. Biosystems Engineering, 87, 27-28.

Shumand, C. S. and R. F. Ambrose. 2003. A comparison of remote sensing and ground-based methods for monitoring wetland restoration success. Restoration Ecology, 11, 325-333. 
Stark, R. and A. Gitelson. 2000. Radiation regime in irrigated wheat. In Proceedings of the Second International Conference on Geospatial Information in Agriculture and For, 89-96.

Szidarovszky, F., M. E. Gershon and L. Duckstein. 1986. Techniques for multiobjective decision making in systems management. pp. 506 (Amsterdam: Elsevier Science Publishing, Co.).

Thomson, S. J., P. V. Zimpa, C. T. Bryson and V. Alarcon. 2005. Potential for remote sensing from agricultural aircraft using digital video. Applied Engineering in Agriculture, 21, 531-537.

Tomlins, G. F., Y. J. Lee. 1983. Remotely piloted aircraft: an inexpensive option for large-scale aerial photography in forestry applications. Canadian Journal of Remote Sensing, 9, 76-85.

Xue, L., W. Cao, W. Luo, T. Dai and Y. Zhu. 2004. Monitoring leaf nitrogen status in rice with canopy spectral reflectance. Agronomy Journal, 96, 135-142. 


\section{APPENDIX}

Table 3. Attribute rankings.

\begin{tabular}{|c|c|c|c|c|c|c|c|c|c|}
\hline Ranking & $\begin{array}{c}\text { System } \\
\text { cost }\end{array}$ & $\begin{array}{l}\text { Data } \\
\text { cost }\end{array}$ & Efficiency & Flexibility & $\begin{array}{l}\text { Payload } \\
\text { capacity }\end{array}$ & $\begin{array}{c}\text { Spatial } \\
\text { coverage }\end{array}$ & $\begin{array}{c}\text { Repeat } \\
\text { coverage }\end{array}$ & $\begin{array}{l}\text { Spectral } \\
\text { resolution }\end{array}$ & $\begin{array}{c}\text { Spatial } \\
\text { resolution }\end{array}$ \\
\hline Expert 1 & 15 & 15 & 25 & 15 & 5 & 5 & 5 & 5 & 10 \\
\hline Expert 2 & 5 & 15 & 20 & 5 & 5 & 5 & 15 & 15 & 15 \\
\hline Expert 3 & 0 & 15 & 15 & 15 & 5 & 10 & 15 & 15 & 10 \\
\hline Expert 4 & 12 & 12 & 24 & 5 & 2 & 10 & 5 & 20 & 10 \\
\hline Expert 5 & 0 & 10 & 10 & 0 & 0 & 20 & 20 & 20 & 20 \\
\hline
\end{tabular}

Table 4. Decision matrix of the experts (1-5).

\begin{tabular}{|c|c|c|c|c|c|c|c|c|c|}
\hline Platform/sensor & $\begin{array}{c}\text { System } \\
\text { cost }\end{array}$ & $\begin{array}{l}\text { Data } \\
\text { cost }\end{array}$ & Efficiency & Flexibility & $\begin{array}{l}\text { Payload } \\
\text { capacity }\end{array}$ & $\begin{array}{c}\text { Spatial } \\
\text { coverage }\end{array}$ & $\begin{array}{c}\text { Repeat } \\
\text { coverage }\end{array}$ & $\begin{array}{l}\text { Spectral } \\
\text { resolution }\end{array}$ & $\begin{array}{c}\text { Spatial } \\
\text { resolution }\end{array}$ \\
\hline Booms & 5 & 2 & 1 & 6 & 8 & 10 & 1 & 1 & 1 \\
\hline Hand held sensors & 2 & 2 & 1 & 1 & 5 & 7 & 1 & 1 & 1 \\
\hline RPVs & 4 & 4 & 4 & 4 & 8 & 7 & 5 & 4 & 1 \\
\hline UAVs & 7 & 4 & 6 & 4 & 7 & 6 & 5 & 4 & 1 \\
\hline Manned aircraft & 9 & 6 & 8 & 6 & 4 & 3 & 8 & 2 & 3 \\
\hline Quickbird & 1 & 10 & 1 & 7 & 1 & 8 & 9 & 4 & 1 \\
\hline
\end{tabular}




\begin{tabular}{|c|c|c|c|c|c|c|c|c|c|}
\hline Landsat & 1 & 5 & 5 & 5 & 1 & 5 & 7 & 3 & 3 \\
\hline AVHRR & 1 & 2 & 10 & 9 & 1 & 1 & 1 & 8 & 10 \\
\hline MODIS & 1 & 2 & 6 & 9 & 1 & 1 & 1 & 2 & 7 \\
\hline ASTER & 1 & 3 & 4 & 5 & 1 & 5 & 7 & 2 & 3 \\
\hline SPOT & 1 & 3 & 7 & 9 & 1 & 1 & 2 & 6 & 9 \\
\hline
\end{tabular}

Table 4 (Expert 2)

\begin{tabular}{|c|c|c|c|c|c|c|c|c|c|}
\hline Platform/Sensor & $\begin{array}{c}\text { System } \\
\text { cost }\end{array}$ & $\begin{array}{l}\text { Data } \\
\text { cost }\end{array}$ & Efficiency & Flexibility & $\begin{array}{l}\text { Payload } \\
\text { capacity }\end{array}$ & $\begin{array}{c}\text { Spatial } \\
\text { coverage }\end{array}$ & $\begin{array}{c}\text { Repeat } \\
\text { coverage }\end{array}$ & $\begin{array}{l}\text { Spectral } \\
\text { resolution }\end{array}$ & $\begin{array}{c}\text { Spatial } \\
\text { resolution }\end{array}$ \\
\hline Booms & 5 & 1 & 2 & 3 & 10 & 10 & 1 & 2 & 1 \\
\hline Hand held sensors & 5 & 1 & 1 & 1 & 10 & 10 & 1 & 2 & 1 \\
\hline RPVs & 2 & 2 & 7 & 2 & 10 & 10 & 2 & 10 & 2 \\
\hline UAVs & 3 & 2 & 7 & 3 & 8 & 8 & 4 & 8 & 2 \\
\hline Manned aircraft & 5 & 5 & 3 & 3 & 2 & 2 & 5 & 4 & 2 \\
\hline Quickbird & 1 & 8 & 5 & 3 & 1 & 8 & 2 & 7 & 1 \\
\hline Landsat & 1 & 4 & 9 & 10 & 1 & 5 & 5 & 6 & 5 \\
\hline AVHRR & 1 & 1 & 10 & 10 & 1 & 1 & 1 & 7 & 8 \\
\hline MODIS & 1 & 1 & 10 & 10 & 1 & 1 & 1 & 4 & 6 \\
\hline ASTER & 1 & 3 & 8 & 10 & 1 & 6 & 5 & 5 & 5 \\
\hline SPOT & 1 & 10 & 5 & 10 & 1 & 6 & 4 & 7 & 5 \\
\hline
\end{tabular}




\begin{tabular}{|c|c|c|c|c|c|c|c|c|c|}
\hline \multicolumn{10}{|c|}{ Table 4 (Expert 3) } \\
\hline Platform/Sensor & $\begin{array}{c}\text { System } \\
\text { cost }\end{array}$ & $\begin{array}{l}\text { Data } \\
\text { cost }\end{array}$ & Efficiency & Flexibility & $\begin{array}{l}\text { Payload } \\
\text { capacity }\end{array}$ & $\begin{array}{c}\text { Spatial } \\
\text { coverage }\end{array}$ & $\begin{array}{c}\text { Repeat } \\
\text { coverage }\end{array}$ & $\begin{array}{c}\text { Spectral } \\
\text { resolution }\end{array}$ & $\begin{array}{c}\text { Spatial } \\
\text { resolution }\end{array}$ \\
\hline Booms & 1 & 6 & 8 & 8 & 10 & 10 & 1 & 1 & 1 \\
\hline Hand held sensors & 1 & 6 & 8 & 8 & 10 & 10 & 1 & 1 & 1 \\
\hline RPVs & 2 & 6 & 8 & 8 & 9 & 10 & 10 & 3 & 1 \\
\hline UAVs & 5 & 6 & 8 & 8 & 8 & 7 & 7 & 3 & 2 \\
\hline Manned aircraft & 10 & 8 & 8 & 8 & 7 & 5 & 5 & 7 & 3 \\
\hline Quickbird & 1 & 10 & 1 & 1 & 1 & 10 & 10 & 5 & 1 \\
\hline Landsat & 1 & 1 & 10 & 10 & 1 & 5 & 5 & 4 & 5 \\
\hline AVHRR & 1 & 1 & 1 & 10 & 1 & 1 & 1 & 3 & 10 \\
\hline MODIS & 1 & 1 & 1 & 10 & 1 & 1 & 1 & 1 & 10 \\
\hline ASTER & 1 & 1 & 1 & 10 & 1 & 7 & 7 & 3 & 3 \\
\hline SPOT & 1 & 7 & 4 & 3 & 1 & 7 & 1 & 5 & 4 \\
\hline
\end{tabular}




\begin{tabular}{lllllllllc}
\hline \multicolumn{10}{c}{ Table 4 (Expert 4) } \\
\hline Platform/Sensor & $\begin{array}{c}\text { System } \\
\text { cost }\end{array}$ & $\begin{array}{c}\text { Data } \\
\text { cost }\end{array}$ & Efficiency & Flexibility & $\begin{array}{c}\text { Payload } \\
\text { capacity }\end{array}$ & $\begin{array}{c}\text { Spatial } \\
\text { coverage }\end{array}$ & $\begin{array}{c}\text { Repeat } \\
\text { coverage }\end{array}$ & $\begin{array}{c}\text { Spectral } \\
\text { resolution }\end{array}$ & $\begin{array}{c}\text { Spatial } \\
\text { resolution }\end{array}$ \\
\hline Booms & 1 & 1 & 3 & 1 & 5 & 10 & 1 & 6 & 1 \\
Hand held sensors & 1 & 1 & 2 & 2 & 5 & 10 & 3 & 6 & 1 \\
RPVs & 6 & 1 & 7 & 5 & 10 & 3 & 5 & 10 & 1 \\
UAVs & 8 & 1 & 7 & 5 & 10 & 1 & 5 & 10 & 1 \\
Manned aircraft & 10 & 1 & 7 & 8 & 1 & 1 & 7 & 1 & 2 \\
Quickbird & 1 & 10 & 8 & 8 & 1 & 8 & 8 & 6 & 3 \\
Landsat & 1 & 2 & 6 & 9 & 1 & 5 & 6 & 3 & 6 \\
AVHRR & 1 & 1 & 1 & 9 & 1 & 1 & 1 & 3 & 10 \\
MODIS & 1 & 1 & 6 & 9 & 1 & 1 & 3 & 1 & 9 \\
ASTER & 1 & 1 & 6 & 9 & 1 & 3 & 6 & 2 & 6 \\
SPOT & 1 & 8 & 8 & 8 & 1 & 5 & 8 & 6 & 6
\end{tabular}




\begin{tabular}{|c|c|c|c|c|c|c|c|c|c|}
\hline \multicolumn{10}{|c|}{ Table 4 (Expert 5) } \\
\hline Platform/Sensor & $\begin{array}{c}\text { System } \\
\text { cost }\end{array}$ & $\begin{array}{l}\text { Data } \\
\text { cost }\end{array}$ & Efficiency & Flexibility & $\begin{array}{l}\text { Payload } \\
\text { capacity }\end{array}$ & $\begin{array}{c}\text { Spatial } \\
\text { coverage }\end{array}$ & $\begin{array}{c}\text { Repeat } \\
\text { coverage }\end{array}$ & $\begin{array}{c}\text { Spectral } \\
\text { resolution }\end{array}$ & $\begin{array}{c}\text { Spatial } \\
\text { resolution }\end{array}$ \\
\hline Booms & 5 & 3 & 1 & 4 & 5 & 10 & 6 & 3 & 3 \\
\hline Hand held sensors & 5 & 3 & 1 & 4 & 5 & 10 & 6 & 3 & 3 \\
\hline RPVs & 3 & 3 & 1 & 3 & 5 & 6 & 5 & 5 & 3 \\
\hline UAVs & 3 & 3 & 1 & 3 & 4 & 6 & 5 & 5 & 3 \\
\hline Manned aircraft & 4 & 3 & 1 & 5 & 3 & 3 & 5 & 3 & 2 \\
\hline Quickbird & 1 & 5 & 10 & 7 & 1 & 5 & 4 & 5 & 2 \\
\hline Landsat & 1 & 2 & 10 & 5 & 1 & 3 & 3 & 4 & 4 \\
\hline AVHRR & 1 & 1 & 5 & 2 & 1 & 1 & 1 & 6 & 7 \\
\hline MODIS & 1 & 1 & 10 & 1 & 1 & 1 & 1 & 3 & 5 \\
\hline ASTER & 1 & 2 & 10 & 5 & 1 & 3 & 4 & 2 & 4 \\
\hline SPOT & 1 & 2 & 10 & 5 & 1 & 1 & 1 & 4 & 7 \\
\hline
\end{tabular}

Table 5. Platform/sensor attribute ratings multiplied by the attribute ranking (for experts 1-5).

\begin{tabular}{|c|c|c|c|c|c|c|c|c|c|}
\hline Platform/sensor & $\begin{array}{c}\text { System } \\
\text { cost }\end{array}$ & $\begin{array}{l}\text { Data } \\
\text { cost }\end{array}$ & Efficiency & Flexibility & $\begin{array}{l}\text { Payload } \\
\text { capacity }\end{array}$ & $\begin{array}{c}\text { Spatial } \\
\text { coverage }\end{array}$ & $\begin{array}{c}\text { Repeat } \\
\text { coverage }\end{array}$ & $\begin{array}{l}\text { Spectral } \\
\text { resolution }\end{array}$ & $\begin{array}{l}\text { Spatial } \\
\text { resolution }\end{array}$ \\
\hline Booms & 75 & 30 & 25 & 90 & 40 & 50 & 5 & 5 & 10 \\
\hline Hand held sensors & 30 & 30 & 25 & 15 & 25 & 35 & 5 & 5 & 10 \\
\hline RPVs & 60 & 60 & 100 & 60 & 40 & 35 & 25 & 20 & 10 \\
\hline
\end{tabular}




\begin{tabular}{llllllllll} 
UAVs & 105 & 60 & 150 & 60 & 35 & 30 & 25 & 20 & 10 \\
Manned aircraft & 135 & 90 & 200 & 90 & 20 & 15 & 40 & 10 & 30 \\
Quickbird & 15 & 150 & 25 & 105 & 5 & 40 & 45 & 20 & 10 \\
Landsat & 15 & 75 & 125 & 75 & 5 & 25 & 35 & 15 & 30 \\
AVHRR & 15 & 30 & 250 & 135 & 5 & 5 & 5 & 40 & 100 \\
MODIS & 15 & 30 & 150 & 135 & 5 & 5 & 5 & 10 & 70 \\
ASTER & 15 & 45 & 100 & 75 & 5 & 25 & 35 & 10 & 30 \\
SPOT & 15 & 45 & 175 & 135 & 5 & 5 & 10 & 30 & 90 \\
\hline \multicolumn{1}{c}{$\quad$} & & & Table 5 (Expert 2) & & & & \\
\multicolumn{1}{c}{ Platform } & System & Data & & & Payload & Spatial & Repeat & Spectral & Spatial \\
Booms & cost & cost & Efficiency & Flexibility & capacity & coverage & coverage & resolution & resolution \\
Hand held sensors & 25 & 15 & 40 & 15 & 50 & 50 & 15 & 30 & 15 \\
RPVs & 25 & 15 & 20 & 5 & 50 & 50 & 15 & 30 & 15 \\
UAVs & 10 & 30 & 140 & 10 & 50 & 50 & 30 & 150 & 30 \\
Manned aircraft & 15 & 30 & 140 & 15 & 40 & 40 & 60 & 120 & 30 \\
Quickbird & 25 & 75 & 60 & 15 & 10 & 10 & 75 & 60 & 30 \\
Landsat & 5 & 120 & 100 & 15 & 5 & 40 & 30 & 105 & 15 \\
AVHRR & 5 & 60 & 180 & 50 & 5 & 25 & 75 & 90 & 75 \\
MODIS & 5 & 15 & 200 & 50 & 5 & 5 & 15 & 105 & 120 \\
ASTER & 5 & 15 & 200 & 50 & 5 & 5 & 15 & 60 & 90 \\
SPOT & 5 & 45 & 160 & 50 & 5 & 30 & 75 & 75 & 75 \\
\hline & 5 & 150 & 100 & 50 & 5 & 30 & 60 & 105 & 75 \\
\hline
\end{tabular}




\begin{tabular}{|c|c|c|c|c|c|c|c|c|c|}
\hline \multicolumn{10}{|c|}{ Table 5 (Expert 3 ) } \\
\hline Hand held sensors & 0 & 90 & 120 & 120 & 50 & 100 & 15 & 15 & 10 \\
\hline RPVs & 0 & 90 & 120 & 120 & 45 & 100 & 150 & 45 & 10 \\
\hline Manned aircraft & 0 & 120 & 120 & 120 & 35 & 50 & 75 & 105 & 30 \\
\hline Quickbird & 0 & 150 & 15 & 15 & 25 & 100 & 150 & 75 & 10 \\
\hline Landsat & 0 & 15 & 150 & 150 & 5 & 50 & 75 & 60 & 50 \\
\hline AVHRR & 0 & 15 & 15 & 150 & 5 & 10 & 15 & 45 & 100 \\
\hline \multicolumn{10}{|c|}{ Table 5 (Expert 4) } \\
\hline Platform & $\begin{array}{c}\text { System } \\
\text { cost }\end{array}$ & $\begin{array}{l}\text { Data } \\
\text { cost }\end{array}$ & Efficiency & Flexibility & $\begin{array}{l}\text { Payload } \\
\text { capacity }\end{array}$ & $\begin{array}{c}\text { Spatial } \\
\text { coverage }\end{array}$ & $\begin{array}{c}\text { Repeat } \\
\text { coverage }\end{array}$ & $\begin{array}{c}\text { Spectral } \\
\text { resolution }\end{array}$ & $\begin{array}{c}\text { Spatial } \\
\text { resolution }\end{array}$ \\
\hline Booms & 12 & 12 & 72 & 5 & 10 & 100 & 5 & 120 & 10 \\
\hline Hand held sensors & 12 & 12 & 48 & 10 & 10 & 100 & 15 & 120 & 10 \\
\hline
\end{tabular}

Misr J. Ag. Eng., January 2009 


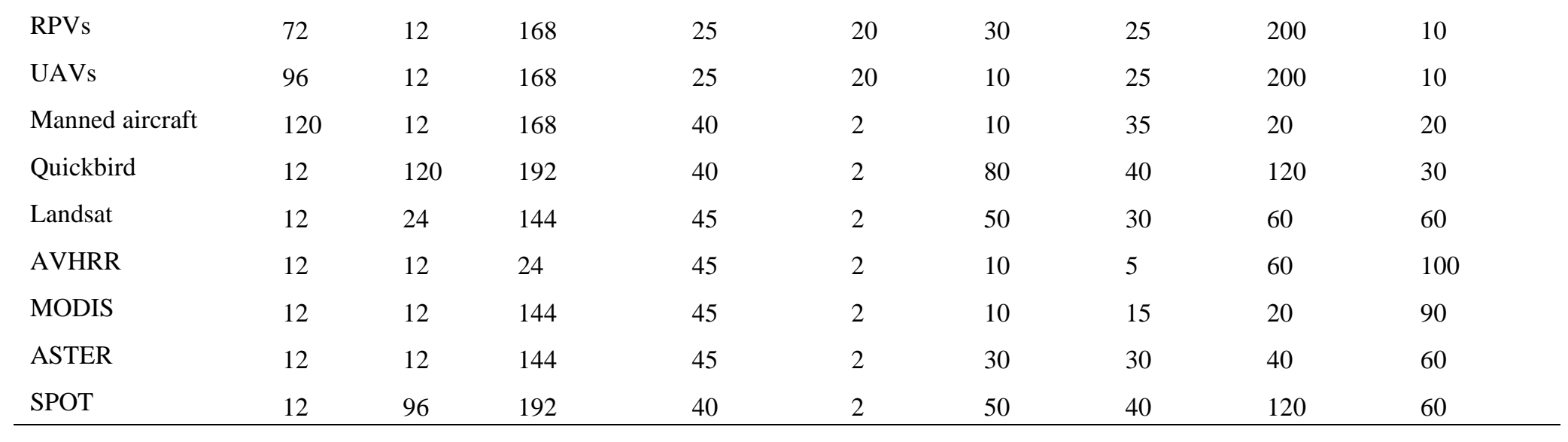

\begin{tabular}{|c|c|c|c|c|c|c|c|c|c|}
\hline \multicolumn{10}{|c|}{ Table 5 (Expert 5) } \\
\hline Platform & $\begin{array}{c}\text { System } \\
\text { cost }\end{array}$ & $\begin{array}{l}\text { Data } \\
\text { cost }\end{array}$ & Efficiency & Flexibility & $\begin{array}{l}\text { Payload } \\
\text { capacity }\end{array}$ & $\begin{array}{c}\text { Spatial } \\
\text { coverage }\end{array}$ & $\begin{array}{c}\text { Repeat } \\
\text { coverage }\end{array}$ & $\begin{array}{l}\text { Spectral } \\
\text { resolution }\end{array}$ & $\begin{array}{c}\text { Spatial } \\
\text { resolution }\end{array}$ \\
\hline Booms & 60 & 36 & 24 & 20 & 10 & 100 & 30 & 60 & 30 \\
\hline Hand held sensors & 60 & 36 & 24 & 20 & 10 & 100 & 30 & 60 & 30 \\
\hline RPVs & 36 & 36 & 24 & 15 & 10 & 60 & 25 & 100 & 30 \\
\hline UAVs & 36 & 36 & 24 & 15 & 8 & 60 & 25 & 100 & 30 \\
\hline Manned aircraft & 48 & 36 & 24 & 25 & 6 & 30 & 25 & 60 & 20 \\
\hline Quickbird & 12 & 60 & 240 & 35 & 2 & 50 & 20 & 100 & 20 \\
\hline Landsat & 12 & 24 & 240 & 25 & 2 & 30 & 15 & 80 & 40 \\
\hline
\end{tabular}




\begin{tabular}{|c|c|c|c|c|c|c|c|c|c|}
\hline AVHRR & 12 & 12 & 120 & 10 & 2 & 10 & 5 & 120 & 70 \\
\hline MODIS & 12 & 12 & 240 & 5 & 2 & 10 & 5 & 60 & 50 \\
\hline ASTER & 12 & 24 & 240 & 25 & 2 & 30 & 20 & 40 & 40 \\
\hline SPOT & 12 & 24 & 240 & 25 & 2 & 10 & 5 & 80 & 70 \\
\hline
\end{tabular}


Table 6. Sum of weighted alternatives.

\begin{tabular}{llllll}
\hline \multicolumn{1}{c}{ Platform/Sensor } & Expert 1 & Expert 2 & Expert 3 & Expert 4 & Expert 5 \\
\hline Booms & 330 & 255 & 520 & 346 & 370 \\
Hand held sensors & 180 & 225 & 520 & 337 & 370 \\
RPVs $^{1}$ & 410 & 500 & 680 & 562 & 336 \\
UAVs $^{1}$ & 495 & 490 & 610 & 566 & 334 \\
Manned aircraft $^{1}$ & 630 & 360 & 655 & 427 & 274 \\
Quickbird & 415 & 435 & 540 & 636 & 539 \\
Landsat & 400 & 565 & 555 & 427 & 468 \\
AVHRR & 585 & 520 & 355 & 270 & 361 \\
MODIS & 425 & 445 & 325 & 350 & 396 \\
ASTER & 340 & 520 & 435 & 375 & 433 \\
SPOT & 510 & 580 & 425 & 612 & 468 \\
\hline
\end{tabular}

Table 7. Ranking of alternatives by expert.

\begin{tabular}{llllll}
\hline \multicolumn{1}{c}{ Platform/Sensor } & Expert 1 & Expert 2 & Expert 3 & Expert 4 & Expert 5 \\
\hline Booms & 2 & 2 & 0.5 & 2 & 0.5 \\
Hand held sensors & 1 & 1 & 0.5 & 1 & 0.5 \\
RPVs $^{1}$ & 1 & 3 & 3 & 2 & 3 \\
UAVs $^{1}$ & 2 & 2 & 1 & 3 & 2 \\
Manned aircraft $^{1}$ & 3 & 1 & 2 & 1 & 1 \\
Quickbird & 3 & 1 & 5 & 6 & 6 \\
Landsat & 2 & 5 & 6 & 4 & 4.5 \\
AVHRR & 6 & 3 & 2 & 1 & 1 \\
MODIS & 4 & 2 & 1 & 2 & 2 \\
ASTER & 1 & 3 & 4 & 3 & 3 \\
SPOT & 5 & 6 & 3 & 5 & 4.5 \\
\hline
\end{tabular}


Table 8. Modified table for the Hare system.

\begin{tabular}{llllll}
\hline \multicolumn{1}{c}{ Platform/Sensor } & Expert 1 & Expert 2 & Expert 3 & Expert 4 & Expert 5 \\
\hline Quickbird & 2 & 1 & 4 & 4 & 4 \\
AVHRR & 4 & 3 & 2 & 1 & 1 \\
MODIS & 3 & 2 & 1 & 2 & 2 \\
ASTER & 1 & 3 & 3 & 3 & 3 \\
\hline
\end{tabular}

Table 9. Calculated results for pairwise voting.

\begin{tabular}{|c|c|c|c|c|}
\hline \multicolumn{5}{|c|}{ Group 1} \\
\hline \multicolumn{5}{|l|}{$A_{1}-\mathbf{A}_{2}$} \\
\hline \multicolumn{5}{|l|}{$0-\mathbf{3}$} \\
\hline \multicolumn{5}{|c|}{ Group 2} \\
\hline$A_{3}-A_{4}$ & $\mathrm{~A}_{3}-\mathbf{A}_{5}$ & \multicolumn{3}{|l|}{$\mathrm{A}_{4}-\mathbf{A}_{5}$} \\
\hline $2-3$ & $1-4$ & \multicolumn{3}{|l|}{$2-3$} \\
\hline \multicolumn{5}{|c|}{ Group 3} \\
\hline $\mathrm{A}_{6}-\mathbf{A}_{7}$ & $\mathrm{~A}_{6}-\mathbf{A}_{8}$ & $\mathrm{~A}_{6}-\mathbf{A}_{9}$ & $\mathrm{~A}_{6}-\mathbf{A}_{10}$ & $\mathbf{A}_{6}-\mathrm{A}_{11}$ \\
\hline \multirow[t]{9}{*}{$2-3$} & $2-3$ & $2-3$ & $1-4$ & $2-3$ \\
\hline & $\mathrm{A}_{7}-\mathbf{A}_{\mathbf{8}}$ & $\mathrm{A}_{7}-\mathbf{A} \mathbf{9}$ & $\mathrm{A}_{7}-\mathbf{A}_{10}$ & $\mathbf{A}_{7}-\mathbf{A}_{11}$ \\
\hline & $1-4$ & $1-4$ & $0-5$ & $3-1$ \\
\hline & & $\mathrm{A}_{8}-\mathbf{A}_{9}$ & $\mathbf{A}_{8}-\mathrm{A}_{10}$ & $\mathbf{A}_{8}-\mathbf{A}_{11}$ \\
\hline & & $2-3$ & $3-1$ & $4-1$ \\
\hline & & & $\mathrm{A}_{9}-\mathbf{A}_{10}$ & $\mathbf{A}_{9}-\mathrm{A}_{11}$ \\
\hline & & & $4-1$ & $5-0$ \\
\hline & & & & $\mathbf{A}_{10}-\mathrm{A}_{11}$ \\
\hline & & & & $4-1$ \\
\hline
\end{tabular}


Table 10. Summary of best overall technology.

\begin{tabular}{lllll}
\hline \multicolumn{1}{c}{$\begin{array}{c}\text { Social Choice } \\
\text { Method }\end{array}$} & \multicolumn{1}{c}{ Plurality voting } & Borda count & \multicolumn{1}{c}{ Hare system } & Pair-wis \\
\hline Group 1 & Hand held sensors & Hand held sensors & Hand held sensors & Hand held se \\
Group 2 & Manned aircraft & Manned aircraft & Manned aircraft & Manned airc \\
Group 3 & AVHRR & MODIS & AVHRR & MODIS \\
\hline
\end{tabular}
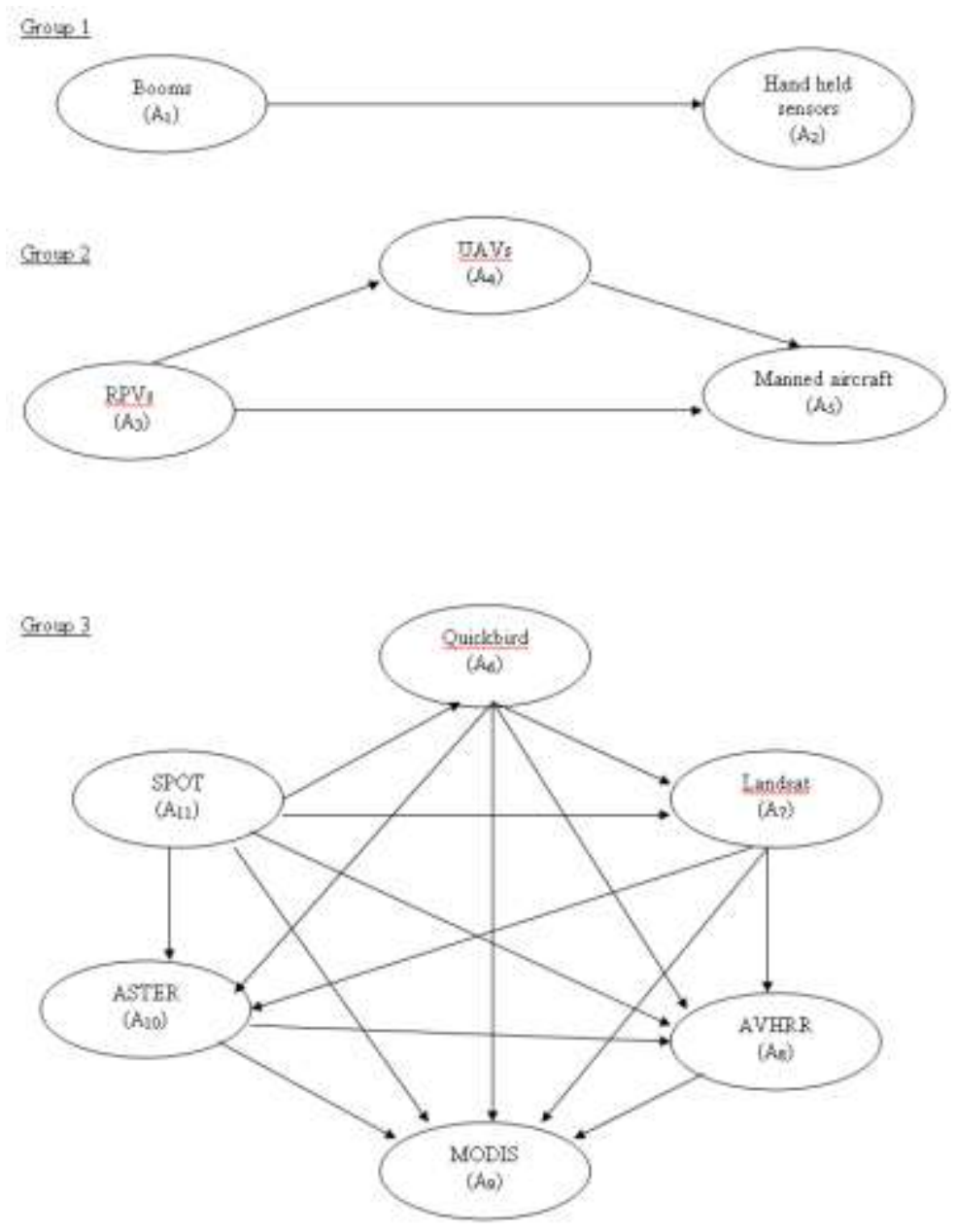

Figure 1. Graphs showing pair-wise comparisons. 


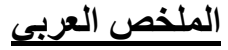 \\ اختيار أنسب نظام استشعار عن بعد للتقييم الزراعي باستخدام تحليل الأهداف الفئ المتعددة}

\section{أ. رونهورس'، ض. الشيخةّ، ف. سيداروفسكيّ و ب. وولر'}

يعتبر الاستشعار عن بعد تكنولوجيا موفرة للمال عند الرغبة في تطبيق نظام إدارة الموقع المحدد (site specific management)

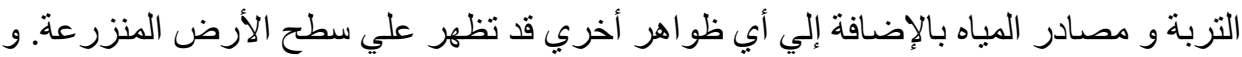

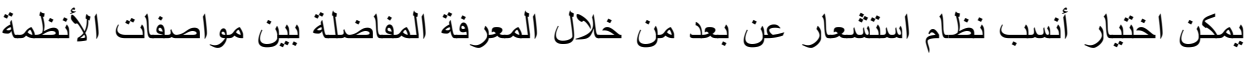

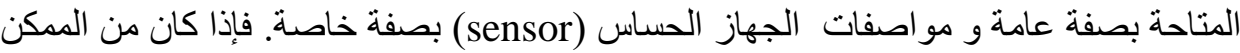
التقدير الكمي لهذه المو اصفات فيمكن استخدام التحليل المسمي بتحليل الأهداف المتعددة ( multi (objective analysis و هذا البحث من أوائل الأبحاث التي تستخدم تحليل الأهداف المتعددة لاختيار أنسب نظام نظدام استشعار عن بعد. و لقد تم إرسال استمارة استبيان لمتخصصين في مجال الاستشعار عن بعد لتقييم الأنظمة المختلفة

$$
\begin{aligned}
& \text { و اختيار أنسب نظام حسب درجة الوضوح المطلوبة: }
\end{aligned}
$$

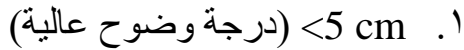

$$
\begin{aligned}
& \text { 0.5-1.0 m . ب (درجة وضوح متوسطة لعالية) } \\
& \text { r. 0.1-1 km (درجة وضوح عادية لمتوسطة ) }
\end{aligned}
$$

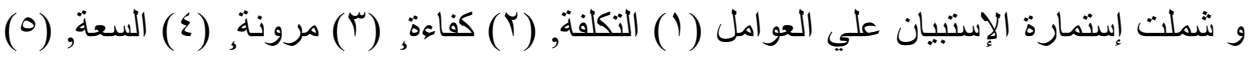

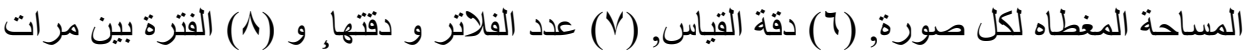
التصوير المتتالية. و يقيم المتخصص كل نظام من أنظمة الإستشعار عن بعد كما يلي:

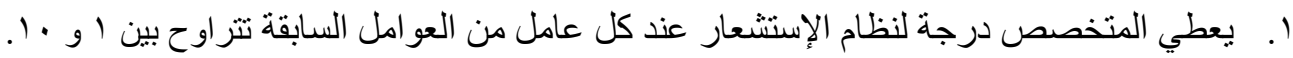

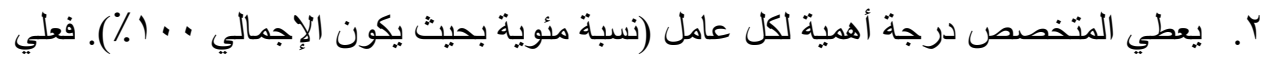

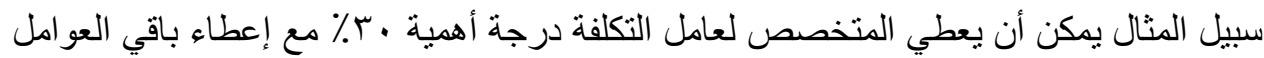

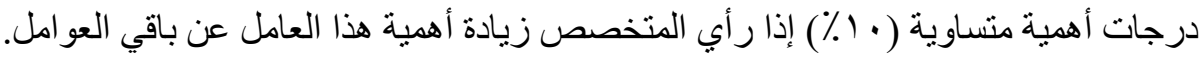

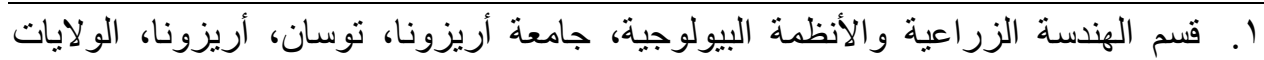
المتحدة الأمريكية

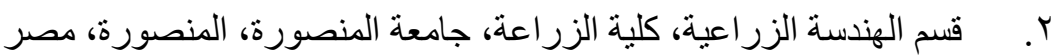

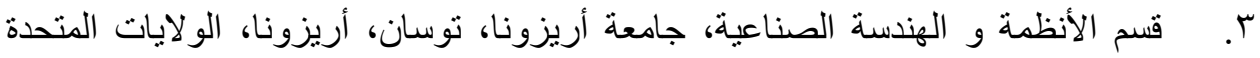
الأمريكية 
و لقد تضمنت أنظمة الاستشعار عن بعد تحت الدر اسة الأنظمة التالية:

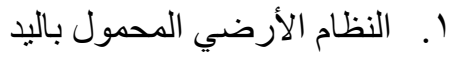

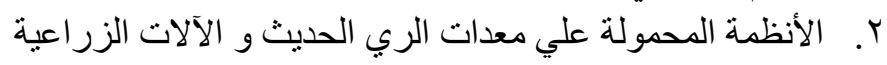

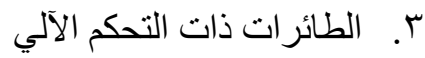

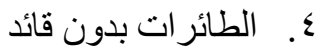

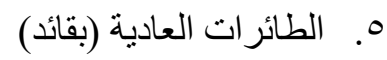

T. الأقمار الصناعية ( (and SPOT

و لقد بينت النتائج أن النظام المحمول باليد و الطائرات العادية (بقائد) هما من أفضل الأنظمة

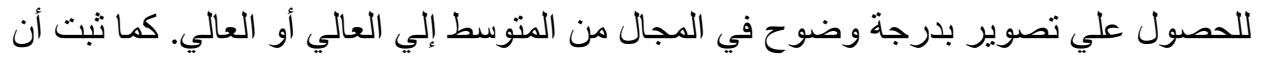

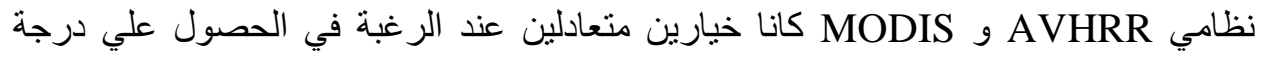
وضوح في المجال من العادي إلي المتوسط. 